\title{
Sharia Micro Financing for Women Poverty Reduction: an Empirical Study of Rural Areas of Kuningan -West Java - Indonesia
}

\author{
Ayus Ahmad Yusuf \\ IAIN Syekh Nurjati Cirebon \\ Cirebon, Indonesia \\ ayusayusuf@yahoo.co.id
}

\author{
Rina Masruroh, Neni Nurhayati \\ Universitas Kuningan \\ Kuningan, Indonesia \\ rektorat@uniku.ac.id
}

\begin{abstract}
Sharia Microfinancing for Women Poverty Reduction: An Empirical Study of Rural Areas of Kuningan West Java - Indonesia. Sharia microfinance, has achieved an everlasting fame in all over the world by producing considerable evidence of property eradication. It provides financial services to those people, who have low income, minimal assets and don't have collateral to borrow a credit from commercial banks. The aim of the sharia microfinance is to remove property by empowering poor and the unbanked with a little amount of credit especially for the women. Present study is conducted to find out of impact of sharia micro financing by Bait al Maal wa Tamwil (BMT) in rural areas of Kuningan West Java Indonesia. A sample of 78 borrowers was randomly selected. Sample unit was the borrower who had completely repaid all the loan installments one week before from the day of survey. Survey technique was used and face to face interviews were conducted to collect the relevant information. Descriptive statistics was used and analyze the characteristics of the borrowers while for econometric analysis, Multiple Linear Regression Model (MLRM) was used to know the impact of micro financing. The study not only reveals the impact of sharia microfinancing but also gives some suggestion implication for the betterment of sharia micro financing schemes.
\end{abstract}

Keywords: Sharia Microfinancing, Women Poverty, Multiple Linear Regression Model (MLRM), Bait al Maal wa Tamwil (BMT).

\section{INTRODUCTION}

In Indonesia especially Kuningan West Java, the population of Kuningan West Java is more than 2 million and majority of the people are living in rural areas. Poverty is a crucial phenomenon which has destroyed not only our economy but also the nation. It is more curses in rural areas because of the lack of the opportunities available there. Rural areas are less developed with least infrastructure, low literacy rate, poor health and educational facilities, unavailability of sufficient food, safe drinking water, improper sanitation system and the most hazardous unemployment; therefore, poverty is more dangerous in rural areas. "One who has lack of basic human needs to spend prosperous or satisfied life; he/she is considered a poor". Poor people cannot borrow loans from formal and informal financial sectors.
Formal sector includes commercial banks that provide large loans at high collateral and poor people are not able to pay any collateral. Similarly, informal lenders charge high interest and keep their adults labor as collateral. Therefore, exploitation of informal lenders, high interest rate and adults as collateral etc. staves off most of the poor people from such formal and informal financial sources. In such crucial circumstances, Microfinance Sector and Small Medium Enterprises (SMEs) came in front to help the poor to get rid from vicious circle of poverty.

"Microfinance is a financial activity to provide small collateral free loans or financial services to the people who have low incomes, minimal assets and who are unable to acquire loans from formal commercial banks because of the demand of high collateral and tight conditions of security" In all over the world, microfinance sector is serving the poor population with the goal of eradicating poverty. Poverty is diversified term but the most common type of poverty is income based poverty. Microfinance increases the incomes of poor borrowers by providing credit for small business, livestock and farming etc. The credit is collateral free and available on easy installments. After proper utilizing the credit incomes of the borrowers' increase which ultimately help them to come out from poverty trap. Hence, microfinance is playing an extensive role in eradication of income based poverty.

The concept of Micro Finance was introduced by the wellknown Bangladeshi Economist Dr. Muhammad Younas in 1976 who has been awarded by noble peace price in the year 2006 for this innovative concept. Dr. Younas established the Grameen Bank in Bangladesh with the unique approach of poor people without any collateral. The loans are group based on the behalf of mutual guarantee of the group member for each other. Peer pressure of the borrower's community urges the members to pay back the installments of loan in time. These loans enable the poor to increase their incomes as well as living standard. Now the concept of micro finance has been broadening and adopted in many developing economies.

In Indonesia especially Goverment of Kuningan West Java established a regulatory frame work to promote microfinance sector throughout the area. Now the BMT (Baitul Maal Wa Tamwil) is working to eradicate poverty from Kuningan West 
Java Indonesia. The study in hand is conducted to reveal the impact of microfinancing by BMT in rural areas of Kuningan West Java.

\section{THE LITERATURE REVIEW}

\section{A. The Role of Micro-Finance in the Empowerment of Women}

The empowerment of women is closely linked with microfinance programs, because many studies have shown that improving women's income through micro-finance has a substantial effect on their empowerment. A vast amount of literature exists on the subject, and the extent to which microfinance programs empower women, is a highly debated subject, which scholars and practitioners tend to disagree upon. Micro-finance is in this thesis defined as an umbrella term which includes loans, savings, insurance, transfer services and other financial products targeted at low-income clients. Empowerment is defined as the fulfilling of the strategic gender needs of women, and as a process by which people get to expand their possibilities to live the kinds of lives they want. This definition is explained more detailed later on.

The basic idea behind micro-finance is to end poverty by increasing people's access to credit be it in the form of institutional credit, or group-based savings involving only financial means from the participants themselves. Often traditional banks and financial institutions have failed to meet the needs of particularly poor women. This has created a need for alternative institutions and programs that meet this group's demand for financial services and saving possibilities. Women constitute the majority of participants in microfinance programs, although the programs initially did not have women as their specific target group

Despite the widespread use of micro-finance as a poverty alleviating empowerment tool, particularly among women, it is subject to various points of critique and discussion. A general criticism towards micro-finance is that the programs rely heavily on donor subsidies. This means that even projects that have been operating for years are unable to function on their own and are unable to fully cover their operational costs. The majority of programs are highly dependent on donor funding, because they do not have the possibility of charging higher interest rates, as these would be too high for borrowers to bear.

Turning towards the role of micro-finance in the empowerment of women, Mayoux states that women's access to credit and women's increased incomes through microfinance do not necessarily change power relations throughout society. Mayoux argues that micro-finance should be linked to a wider women's movement for transformation of gender relations. Pearson furthermore argues that micro-finance has become part of a gender and development initiative because women have come to be the major borrowers, due to their higher inclination to repay and conform to the terms of loans. She nevertheless claims that pure micro-finance programs do not have as their objective to empower women or to transform gender relations.
Linking these statements to the research question of this research and Moser's theory on practical and strategic gender needs of women, this suggests that micro-finance, by increasing women's income, meet their practical gender needs. But, since micro-finance, as argued by Mayoux, does not change power relations throughout society, it cannot be said to meet the strategic gender needs. Pearson's claim that microfinance does not aim at transforming gender relations, supports this argument, but does however not exclude the possibility of micro-finance having an indirect effect on the empowerment of women.

\section{B. Micro finance services}

Micro finance Services refer mainly to small loans; savings mobilization and training in micro enterprise investment services extended to poor people to enable them undertake self-employment projects that generate income. Micro finance came into being from the appreciation that micro entrepreneurs and some poorer clients can be 'bankable', that is, they can repay both the principal and interest, on time and also make savings, provided financial services are tailored to suit their needs (Von, 1991). Micro finance is perceived as the provision of financial and nonfinancial services by micro finance institutions (MFIs) to low income groups without tangible collateral but whose activities are linked to income generating ventures (Lidgerwood, 1999 and Christen and Rosenberg, 2000). These financial services include savings, credit, payment facilities, remittances and insurance. The non-financial services mainly entail training in micro enterprise investment and business skills. There is also a belief that micro finance encompasses micro credit, micro savings and micro insurance (Roth, 2002).

Micro finance is not a new development. Its origin can be traced back to 1976, when Muhammad Yunus set up the Grameen Bank, as experiment, on the outskirts of Chittagong University campus in the village of Jobra, Bangladesh.The aim was to provide collateral free loans to poor people, especially in rural areas, at full-cost interest rates that are repayable in frequent installments. Borrowers were organized into groups and peer pressure among them reduced the risk of default (Khan and Rahaman, 2007). In many cases, basic business skill training should accompany the provision of micro loans to improve the capacity of the poor to use funds (Webster and Fidler, 1996). Micro financing should address capital investment decisions, general business management and risk management. In the world over, provision of micro finance services to the youth has been considered an innovative and sustainable approach to youth financial and micro enterprise activities empowerment leading to generation of income so as to improve their livelihoods and contribute to economic growth.

Debates on extending the reach of microfinance to the very poorest people increasingly focus on savings facilities. For many youth, savings facilities are essential in increasing the amount of income under their control and in building assets. In remote areas, mobilization and intermediation of member savings may be crucial first steps before accessing external loan funds. A number of studies have observed that savingsled groups perform better than credit-led ones (Allen 2005; 
Murray and Rosenberg 2006; Ritchie 2007). Access to microfinance has the potential to assist the poor in earning income from microenterprises, smooth their income and consumption (Zeller, 1999), help households diversify their income sources. (Anand et al., 2005).

According to Mosley (2000) microfinance makes a considerable contribution to the reduction of poverty. It helps increase income earning and asset building opportunities which make households less reliant on a single asset type and consequently deal with disasters. (Anand et.al. 2005). According to Hassan (2002), many Grameen Bank borrowers were actually building larger houses. Panganiban (1998) advances that the income of borrowers has risen and their assets base has widened. Investments made by loans appear to have been extremely productive and to have contributed significant improvements in household output, income and consumption (Ghai, 1984). In Tegucigalpa and Collotheca in Honduras in 2003, effect assessment studies revealed that $60 \%$ and $50 \%$ of the recipients had their sales and incomes increase respectively one year after receipt of credit for working capital. Agricultural Finance Cooperation Limited in 2008 in India, assessed development effect of microfinance programmers. Clients reported increase in income from $76 \%$ of activities. There is therefore reason to believe microfinance services in its entirety should report effect on savings, income and investments alongside non-financial effect such as change in skills through training. This study was specific in investigating these aspects.

\section{Micro Credit}

Micro credit is a way of delivering loans to poor individuals and is often suggested to be a way out of poverty (Armendariz de Aghion and Morduch, 2005 p 8). Microfinance institutions provide microcredit to poor individuals cia their microcredit programs. In addition to microcredit, microfinance institutions usually provide saving and services (Armendariz de Aghion and Morduch, 2005 p 1) In other words, microcredit is a narrower term than microfinance. Microcredit and microcredit programs will be the focus of this study.

Microcredit builds on the premise that financial services are needed to make investments in human capital, to smooth out consumption and to overcome unexpected shocks. It can be seen as a solution to include previously excluded poor groups, without access to credit, to the financial market so that they may rise out of poverty by themselves. Microcredit makes a Positive economic cycle possible. A microcredit granted to a borrower is invested, which generates an income. The loan can be then being repaid to the microfinance institution, and the borrower may then access another microcredit and eventually increase purchasing power and social recognition. Dobra (2011) argues that microcredit not only open up the opportunity of self-Employment, but also contributes to the improvement of the situation for the entire household. Furthermore, microcredit positively effects the social situation of poor individuals by promoting self Confidence and expanding the capacity to play a more important role in society (Dobra, 2011, p.135, 136)
One of the advantages with microcredit over other financial services is the possibility of receiving a group Based loan where member's work as each other's collateral. The advantage of being a group is that the group can loan a larger amount. This amount is then repaid regularly in small sums by each member, which makes it possible for even the poorest borrower to repay his or her loan. If the group makes the prepayments as they should, they can acquire access to repeated and larger loans (Arunetal., 2009, p.13)

\section{Women empowerment}

In the Human Development Report from 2008, UNDP stated that 70 percent of the world's population living on less than 1 USD a day are women (UNDP, 2008). In addition to being poorer than men, women are also more vulnerable, which in part is due to the fact that many developing countries are male dominated societies. A basic assumption is that poverty reduction strategies are related to the promotion of development. Dobra (2011) argues that while in the developmental process, speaking about development without seeking to reduce inequalities between men and women leads to both partial development and partial poverty reduction (Dobra, 2011 p. 136, 137). Furthermore, the World Bank (2012) has stressed that long lasting gender inequalities, characteristic of many developing countries, are restraints on economic growth and development (The World Bank, 2012). With the aim to reduce female fragility and poverty, there has been an increasing expectation on microcredit and other poverty strategies to positively affect women's empowerment.

What is empowerment? The World Bank (2009) defines empowerment as "the process of increasing the capacity of individuals or groups to make choices and to transform those choices into desired actions and outcomes. Central to this process are actions which both build individual and collective assets, and improve the efficiency and fairness of the organizational and institutional context which govern the use of these assets" (World Bank, 2009). Amartya Sen (1993) explains that the freedom to lead different types of life is reflected in a person's capability set. A person's capability depends on a variety of factors including social arrangements characteristics. However, the full accounting of individual freedom goes capabilities of personal living. For example, if a person does not have to choose to live in a certain way, even though she could live that way if she can be said that she does have the freedom to live that way (Sen, 1993, p. 31, 32).

Cornwall, Eyben and Kabeer (2008) defines empowerment as the process that relates to the power of an individual to redefine his or her possibilities and to have the ability to act upon them (Cornwall et al., 2008, p. 5). Kabeer (1999) further defines empowerment as "the expansion in people's ability to make strategic life choices in a context where this ability was previously denied to them." Accordingly, empowerment is about the improvement of individual's capabilities to make a difference in their settings, which in turn affects their life. Empowerment also relates to the influence of an individual on social and cultural norms in society. In contrast to many other terms, women's empowerment relates to a process, a movement from one state to another. Empowerment also includes agency, in which women themselves are actors in the 
empowerment process. Furthermore, agency implies that women must not only be able to make a decision, but be aware of their rights to make it (Kabeer, 1999, p. 437).

\section{E. Microcredit and women empowerment}

How does microcredit lead to women's empowerment? Microcredit enables women empowerment by placing capital in their hands and allowing them to earn independent income and contribute economically to their households and communities (Cheston and Kuhn, 2002, p. 14). In theory, women invest the microcredit in their own income Meaning activity, either in the form of a microenterprise or agricultural production, and accordingly their income, which they themselves control, increases. In other words, involvement in a successful income generating activity should translate into greater control and economic empowerment. Women's economic empowerment is then expected lead to increased wellbeing for themselves and also their families.

Furthermore, this economic empowerment is seen as enabling women to renegotiate changes in gender roles, which may lead to social empowerment (Mayoux, 2001, p. 438, 439). Microcredit may also lead to increased women empowerment through increased power in decision making. Browning and Chiappori (1998) show in their collective decision making model that if behavior in the household is Pareto efficient, the household's objective function takes the form of a weighted sum of individual utilities.

This individual weight can represent the bargaining power of the female member in the household, relative to the male member, in determining the allocation of resources in the household. It is then assumed that by increasing the relative value of the female members' time and income, the weight and therefore the bargaining power of the female can be increased within the household (Browning and Chiappori, 1998, p. 1248, 1249).

Still, one need to question the assumed linkage between microcredit and women empowerment since some studies suggest that microcredit, in some cases, may have been a part of the disempowerment of women. It cannot be assumed that women have control over loan use, even when they are explicitly targeted. For instance, women may be used as low cost intermediaries between microcredit program staff members and male household members. Even in the case where women control the loan, this may not result in significantly increased incomes. Furthermore, even where there is an increase in income for women, there may be no control by women over income.

The male household member may for example take control over the income and use it for personal expenditures. For that very reason, men may be supportive of women's microcredit activities and other income earning activities. By engaging in a microcredit program, women may be forced to cut their own, already inadequate, expenditure on food and health services to repay their loans. The combination of low incomes, lack of control, and repayment pressure may do little to increase women's empowerment (Mayoux, 2000, p. 12, 13).

\section{F. Conceptual Framework}

This conceptual framework depicts an effect relationship between microfinance services and financial empowerment of youth through changes in savings, and investments. Gender, Income levels, lifestyle, values, attitudes, Religion, social groups, educational level, ethnic culture and other issues intervene.

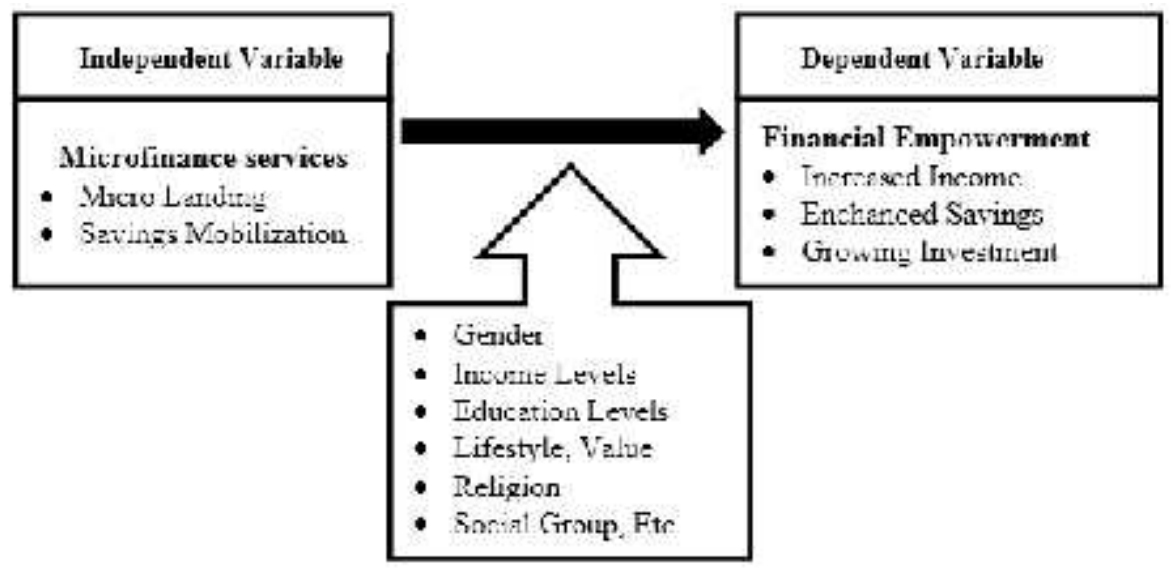

Fig. 1. Source : Author, 2015

\section{METHODOLOGY}

\section{A. Research Design}

A descriptive survey design was adopted. Both qualitative and quantitative techniques were applied. Descriptive research design is connected with providing solutions to the problems.
This design was found appropriate for exploring the effect of micro-finance services on the youth financial empowerment. In order to collect qualitative information depth interviews were conducted with a small number of respondents. 


\section{B. List Of Variable}

1) Dependent Variable :

$\mathrm{Y}=$ Financial Empowerment (Increased Income, Enhanced Savings, Growing Investment)

2) Independent Variable

$\mathrm{X}=$ Microfinance Services (Microfinance Landing, Savings Mobilization)

\section{The Population and Sample}

The Population in this research is 19 Microfinance or BMT (Baitul Maal Wa Tamwil) at Kuningan Regency and The Sample of 78 borrowers was randomly selected.

\section{Data type and Collection Method and Instruments}

Primary and secondary data were used. Structured and Semi structured questionnaire and interview were used to obtain information from the sample. The researcher gathered secondary electronic and hard data from several books, research literatures, articles, journals. Internet sources were also used.

\section{E. Research Instruments' Reliability and Validity}

The questionnaire was refined then pretested in other group other than the actual respondents. This reduced the risk of misunderstanding and misinterpretation by the actual respondents thus improving internal validity of the research instrument. The construct validity was improved through thorough review of literature to ensure that the measurement items conform to theoretical assertions of the concept under study. R-squared was used to assess the reliability of the measuring items in the questionnaire. It is important to emphasize that the study focused on the dynamics of the variables under study to support the theoretical assertions of the concepts under study in line with recommendations by other researchers.

\section{F. Data Analysis and Presentation}

Descriptive analysis was used to summarize the characteristics of the respondents. The Quantitative data was analyzed by use of both the descriptive and inferential statistics. The descriptive statistics involved the use of mean, frequency, percentages and standard deviation. In order to check the relationship between the variables the study used the correlation coefficient and the Chi square for testing relative differences in the

Effectiveness of the microfinance services. Qualitative data were analyzed by using Multiple Linear Regression Model (MLRM). The researcher utilized tables and bar graphs to present the findings.

While qualitative data is analised through several steps namely data reduction, data presentation, and drawing a conclusion

\section{RESULTS AND DISCUSSIONS}

\section{A. The Result}

1) Characteristics of the Borrowers

$$
\text { a) Age }
$$

Age of the sample woman borrowers was asked during the interview, following results are found.

TABLE I. AGE PATREEN

\begin{tabular}{|l|l|}
\hline \multicolumn{1}{|c|}{ Age } & \multicolumn{1}{c|}{ Percentage } \\
\hline 21-30 Year & $0 \%$ \\
\hline 31-40 Year & $29 \%$ \\
\hline 41-50 Year & $46 \%$ \\
\hline $51-60$ Year & $21 \%$ \\
\hline$>60$ Year & $4 \%$ \\
\hline Total & $100 \%$ \\
\hline
\end{tabular}

The age limit for the woman borrowers by BMT is from minimum 21 years to maximum 65 years. It is because of a teen ager is not so much mature that she can use the credit in positive income generating activities. So a chance of loss in any business is high in this age. The person having above 65 years of her age is not physically strong to actively participate in any economic activity. The above table shows that most of the borrowers are lies in the age group of 41 to 50 years.

\section{b) Material Status}

Marital status of the woman borrowers was asked during the interview. Following results are found.

TABLE II. MATERIAL STATUS

\begin{tabular}{|l|l|}
\hline \multicolumn{1}{|c|}{ Material Status } & \multicolumn{1}{|c|}{ Percentage } \\
\hline Married & $87 \%$ \\
\hline Single & $0 \%$ \\
\hline Widowed & $11 \%$ \\
\hline Divorced & $3 \%$ \\
\hline Total & $100 \%$ \\
\hline
\end{tabular}

The above table shows that most of the woman borrowers are found married because most of the married people need a credit to enhance their small scale business to earn profit for their families.

\section{c) Family Structure}

Family structure was also asked to the woman borrowers following results are found the table shows that most of the woman borrowers who borrowed a credit are living in nuclear family system 
TABLE III. FAMILY STRUCTURE

\begin{tabular}{|l|l|}
\hline \multicolumn{1}{|c|}{ Family Structure } & \multicolumn{1}{c|}{ Percentage } \\
\hline Joint Family System & $32 \%$ \\
\hline Nuclear Family System & $68 \%$ \\
\hline Total & $100 \%$ \\
\hline
\end{tabular}

\section{d) Education}

It is found that the education of the sample woman borrower lies between illiteracy to twelve year of schooling and no one has above twelve year of education. It shows that in rural areas education level is very much low

TABLE IV. EDUCATION

\begin{tabular}{|l|l|}
\hline \multicolumn{1}{|c|}{ Education } & \multicolumn{1}{c|}{ Percentage } \\
\hline Illierate & $41 \%$ \\
\hline Primary & $13 \%$ \\
\hline Middle & $36 \%$ \\
\hline Intermediate & $10 \%$ \\
\hline Total & $100 \%$ \\
\hline
\end{tabular}

The above table shows that most of the woman borrowers are found illiterate. Minimum education level is zero years of schooling while maximum education level of sample woman borrowers found twelve years of education.

\section{2) Empirical /Econometric Analysis}

Primary data is interpreted by using software "Statistical Package for Social Sciences" (SPSS). A data, which a researcher is going to be interpret; must be reliable.

\section{a) Reliability}

Reliability is defined as the extent to which a test produces same results on the repeated trials. As Mehrens and Lehman [4] state the reliability means the degree of consistency between two measures of the same thing. The variables which are going to be analyzed by a researcher must have internal consistency that indicates the reliability of the variables. Among the internal consistency methods; Cronbach's alpha [5] is the most common method to measure the reliability. Higher value of coefficient of Cronbach's alpha shows the higher reliability. Nunnaly [6] indicated that 0.7 is the acceptable reliability coefficient. To measure the reliability of the primary data Cronbach's alpha is used. Results are as follows.

TABLE V. RESUlt OF RELIABLITY STATISTIC

Reliability Statistics

\begin{tabular}{|l|l|}
\hline Cronbach's Alpha & N of Items \\
\hline
\end{tabular}
, 833
The above table shows that coefficient of Cronbach's alpha is found 0.809 which indicates the reliability of the data. Model)

b) The Result MLRM (Multiple Linear Regression

TABLE VI. The Result Multiple Linear Regression Model

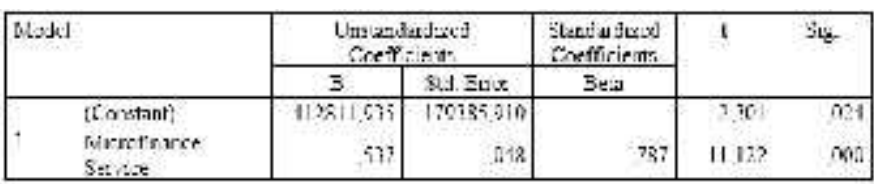

${ }^{\text {a. }}$ Dependent Variable: Financial Empowerment

To find out the influence of the microfinance service on the Financial Empowerment is by using $\mathrm{T}_{\text {test }}$. We use the $\mathrm{T}_{\text {table }}$ by the significance level is 0,05 . DF $=\mathrm{n}-2$ or $78-2=76$. From the table, we can see that the $\mathrm{T}_{\text {table }}$ is 1,68 .

$$
\begin{aligned}
& \text { If } \mathrm{T}_{\text {account }}>\mathrm{T}_{\text {table }}, \mathrm{H} 0 \text { refused and } \mathrm{H} 1 \text { accepted } \\
& \text { If } \mathrm{T}_{\text {account }}<\text { table }, \mathrm{H} 0 \text { accepted and } \mathrm{H} 1 \text { refused }
\end{aligned}
$$

According the data above (table 4.3.1), it shows that the $\mathrm{T}_{\text {account }}$ is 3, 696. Because $\mathrm{T}_{\text {account }}>\mathrm{T}_{\text {table }}(11,122>1,68)$, so $\mathrm{H} 0$ refused and $\mathrm{H} 1$ accepted. It means that there is a linier relation between the microfinance services on the Financial Empowerment. And the strength of the microfinance services influence is 0,787 or $78,7 \%$. And other influence $(21,3 \%$ ) is from another factor.

Based in MLRM testing, it revealed that the increasing in sharia microfinance service will also increase the prosverity of woman in rural area. This is because if there are many woman take benefit from the better servive of sharia microfinance so it will increase productivity and autonomy

TABLE VII. MODEL SUMMARY

\begin{tabular}{|c|c|c|c|c|}
\hline Model & R & R Square & Adjusted R Square & $\begin{array}{c}\text { Std. Error of the } \\
\text { Estimate }\end{array}$ \\
\hline 1 & $1,787^{\mathrm{a}}$ &, 619 &, 614 & 912660,45314 \\
\hline
\end{tabular}

The score of R Square is 0,619 . This score is used to know how big the influence of the microfinance services on the Financial Empowerment together. It is counted by the DC.

$$
\begin{array}{ll}
\text { DC } & =r 2 \times 100 \% \\
\text { DC } & =0,619 \times 100 \% \\
\text { DC } & =61,9 \%
\end{array}
$$

It shows that the microfinance services on the Financial Empowerment is by $61,9 \%$. And 38, $1 \%$ is influenced by the other factors.

The analisys shows that sharia mocrofinance service have a significant influence on woman empowerment at the rural areawith the level of inflence at $61,9 \%$. 
TABLE VIII. ANOVA ${ }^{A}$

\begin{tabular}{|c|c|c|c|c|c|c|}
\hline \multicolumn{2}{|c|}{ Mocid } & $\begin{array}{l}\text { Sum of } \\
\text { Sirnzars:s }\end{array}$ & df & Mcan Squarc & 5 & Sig. \\
\hline \multirow{3}{*}{1} & Regression & $\begin{array}{r}20302863075 \\
540-987\end{array}$ & 1 & $\begin{array}{r}10302008910 \\
5490050\end{array}$ & \multirow[t]{3}{*}{$123,69 \mathrm{~L}$} & \multirow[t]{3}{*}{, $000^{\mathrm{t}}$} \\
\hline & Residua. & $\begin{array}{r}63304171807 \\
61 \equiv .430\end{array}$ & $70^{\circ}$ & $\begin{array}{r}87994 \mathrm{C} 10273 \\
0.506\end{array}$ & & \\
\hline & Tota. & $\begin{array}{r}663798,157 \\
3605,400\end{array}$ & 77 & & & \\
\hline
\end{tabular}

\section{CONCLUSION AND SUGGESTION}

The present study was conducted to know the impact of microfinance in rural areas. The study concludes that microcredit plays an important role in woman poverty eradication by enhancing the income of the poor people especially the poor woman. It enables the poor woman to enhance and use their adequate skills in income generating activities. It makes possible for the poor woman to earn impel profit from small business, build assets, manage risky situations, acquire better opportunities of education and health care, quality of food and nutrition for their families. All these lead to improve the living standard of woman borrowers in the society. Microfinance is also found significant and has positive impact on the woman financial empowerment. Some suggestions are given below for the betterment of BMT and microfinance sector in Kuningan.

- Amount of credit may be increased as per needs of the woman borrowers.

- Interest rate may be significantly decreased

- Government may encourage to other MFIs to launch micro credit programmers for woman in rural areas.

\section{REFERENCE}

[1] Rahman Mizanur Muhammad (2010) Islamic microfiancé programs and its ipact on rural poverty alleviation. The Int. J. Banking and Finance 7(1):119-38

[2] Bashir Khalid Muhammad, Amin Akhtar, Naeem Khalid Muhammad (2010) Micro- credit and poverty alleviation in Pakistan. World Applied Science Journal 8(11):1381-6.
[3] Nunnally J (1978) Psychometric Theory (2nd ed). New York: McGrawHill.

[4] Dobra, A (2011), "Microfinance: Champion in Poverty Alleviation and Failure in Female Empowerment" in Internationale Politik und Gesellschaft, Vol. 3, 2011, pp. 134144

[5] Armendariz de Aghion, B. and Morduch, J. (2005) The Economics of Microfinance, IT Press.

[6] Islam, A. (2007) "Using Non Experimental Methods To Evaluate The Impact of Microfinance: Evidence From Bangladesh", individual paper for The Bangladesh Institute of Development Studies

[7] Islam, T. (2007) Microcredit and Poverty Alleviation, Ashgate Publishing, Ltd

[8] Mayoux, L (2005). Micro-finance and the Empowerment of Women: A Review of Key Issue, Social Finance Unit. IFAD publication.

[9] Mayoux, L. and Hartl M. (2009). Gender and Rural Microfinance: Reaching and Empowering Women, IFAD publication.

[10] Ariesto Hadi Sutopo dan Adrianus Arief, 2010. Judul : Terampil Mengolah Data Kualitatif Dengan VIVO. Penerbit Prenada Media Group : Jakarta

[11] Cornwall,A,Eyben R, and Kabeer (2008), "Conceptualizing empowerment and the implications for propoor growth"A paper for the DAC Poverty Network Institute of Development Studies

[12] Kabeer,(1999)"Resources Agency Achievements Reflections on the Measurement of Women's Empowerment" in Development and Change, Vol.30,No.3,1999,pp.435M 464

[13] UNDP (2008) "Human Development report 2008", New York NY available http://hdr.undp.org/en/media/HDR_20072008_EN_Complete.pdf

[14] The World Bank (2009)"What is empowerment",availableat: http://go.worldbank.org/V45HD4P100

[15] The World Bank (2012) "World Development Report 2012: Gender Equality and Development" available at http://siteresources.worldbank.org/INTWDR2012/Resources/7778105M 1299699968583/7786210M1315936222006/CompleteMReport.pdf, 